\title{
PENCEMARAN NAMA BAIK MELALUI MEDIA SOSIAL: PERBANDINGAN HUKUM PIDANA POSITIF DAN ISLAM
}

\author{
Saepul Rochman \\ Program Studi Perbandingan Mazhab Fakultas Syariah Universitas Darussalam Gontor \\ Email: saepulrochman@unida.gontor.ac.id \\ Haerul Akmal \\ Program Studi Perbandingan Mazhab Fakultas Syariah Universitas Darussalam Gontor \\ Email: haerulakmal@unida.gontor.ac.id \\ Yaffi Jananta Andriansyah \\ Program Studi Perbandingan Mazhab Fakultas Syariah Universitas Darussalam Gontor \\ Email: yaffiandriansyah99@gmail.com
}

\begin{abstract}
This article aims to compare the application of criminal defamation norms through social media. The method used in this study is a normative method with comparative law approach. The results of this study indicate that the criminal act of defamation is sentenced to one year in prison. Whereas in Islamic criminal law as a source of positive law, according to the school of jurisprudence (madzhab) other than Syafi'iyah, the punishment is exile (ta'zir) according to the decision of the caliph or sultan or qadhi. Only the Shafi'iyah school determines through a legal analogy (qiyas). That the defendant is sentenced to one year's seclusion
\end{abstract}

Keywords: Defamation, Comparison, Criminal, Positive.

\begin{abstract}
Abstrak
Artikel ini bertujuan untuk membandingkan penerapan norma tindak pidana pencemaran nama baik melalui media sosial. Metode yang digunakan dalam penelitian ini adalah metode normatif dengan pendekatan perbandingan hukum. Hasil penelitian ini menunjukan bahwa tindak pidana pencemaran nama baik dijatuhi hukuman empat tahun penjara dalam UU ITE. Sedangkan dalam hukum pidana Islam sebagai sumber hukum positif, tindak pidana ini menurut Madzhab selain Syafi'iyah dijatuhi hukuman ta'zir sesuai dengan keputusan khalifah atau sultan maupun qadhi. Hanya madzhab Syafi'iyah yang menentukan melalui analogi hukum (qiyas) bahwa terdakwa di hukum selama satu tahun pengasingan.
\end{abstract}

Kata Kunci: Pencemaran Nama Baik, Perbandingan, Pidana, Positif.

\section{Pendahuluan}

Penggunaan teknologi komunikasi merupakan kebutuhan yang tidak terhindarkan pada era global ditandai dengan berbagai kemudahan yang dapat dipilih oleh masyarakat untuk mengakses berbagai informasi yang berguna. Pengaruh pada perilaku sosial terjadi karena adanya peralihan dari era 
Saepul Rochman, Haerul Akmal \& Yaffi Jananta Andriansyah:

Pencemaran Nama Baik Melalui...

industrialisasi ke era informasi yang kemudian melahirkan masyarakat informasi (information society). Rogers sebagaimana dikutip oleh Amar Ahmad menyatakan bahwa information society adalah sebuah masyarakat yang sebagian besar angkatan kerjanya adalah pekerja di bidang informasi, dan informasi telah menjadi elemen yang dianggap paling penting dalam kehidupan. ${ }^{1}$

Kemajuan teknologi informasi telah mendorong kegiatan manusia ke arah efisiensi di bidang politik, ekonomi dan budaya. Beberapa perusahaan di bidang teknologi informasi atau menggunakan teknologi informasi telah mengalami banyak peningkatan pemasaran dan masyarakat juga mendapatkan akses yang terbuka dan kemudahan atas berbagai produk serta menjadi tempat untuk mengekspresikan diri. $^{2}$

Hanya saja kemajuan teknologi informasi tidak hanya berdampak baik untuk kehidupan manusia, karena prinsip kebebasan (liberalism) yang melatarbelakangi penggunaan teknologi informasi ini. Sebab itu meskipun pengguna (user) diberikan perjanjian (term and condition) pada saat mengakses dan menggunakan teknologi informasi seperti youtube, instagram, dan facebook, belum ada aplikasi yang dapat mendeteksi pernyataan-pernyataan yang tidak sopan atau penghinaan yang dituliskan oleh seorang user dan melakukan tindakan preventif sebelum membagikan pernyataannya, sehingga seseorang dapat dengan mudah menyebarkan dan memprovokasi seseorang, mencemarkan nama baik atau melakukan tindakan tercela lainnya. ${ }^{3}$

Kasus pencemaran nama baik melalui media sosial di Indonesia, telah diatur dalam Undang-Undang No. 11 Tahun 2008 tentang Informasi dan Transaksi Elektronik yang mengatur dalam Pasal 27 ayat (3) yaitu dipidana dengan pidana penjara paling lama 4 (empat) tahun dan/atau denda paling banyak Rp. 750.000.000,00 (tujuh ratus lima puluh juta rupiah). Namun kewenangan mempidana seseorang merupakan kewenangan pengadilan yang diatur dengan berbagai undang-undang. Salah satunya adalah tentang doktrin kebebasan hakim.

${ }^{1}$ Amar Ahmad, "Perkembangan Teknologi Komunikasi dan Informasi: Akar Revolusi dan Berbagai Standarnya", Jurnal Dakwah Tabligh, Vol. 13, No. 1, Juni 2012, hlm. 138

2 Dikdik M Arief Mansur dan Elisatris Gultom, Cyber Law Aspek Hukum Teknologi Informasi, Bandung: Refika Aditama, 2009, hlm. 4.

3 Achmadudin Rajab, “Urgensi Undang-Undang Nomor 19 Tahun 2016 Tentang Perubahan Atas Undang-Undang Nomor 11 Tahun 2008 Tentang Informasi dan Transaksi Elektronik Sebagai Solusi Guna Membangun Etika Bagi Pengguna Media", Jurnal Legislasi Indonesia, Vol. 14 No. 04, 2017, hlm 463.

DIKTUM: Jurnal Syariah dan Hukum Volum 19 Nomor 1 Juli 2021 
Saepul Rochman, Haerul Akmal \& Yaffi Jananta Andriansyah:

Pencemaran Nama Baik Melalui...

Hukum Islam sebagai hukum tidak tertulis di Indonesia merupakan bahan baku dari perumusan hukum positif sehingga menjadi penting untuk didiskusikan, oleh karena itu dalam penelitian ini akan dikaji mengenai hubungan Hukum Islam dan hukum positif yang berkaitan dengan penerapan hukum pidana pencemaran nama baik melalui media sosial, dimana dalam hukum Islam perangkat teknologi informasi merupakan bagian dari perkara-perkara yang baru atau tidak muncul pada masa nabi Muhammad. Penelitian ini juga pada saat yang sama merupakan proses evaluasi terhadap berbagai norma yang digunakan dalam proses pemidanaan.

Al Qur'an sebagai salah satu landasan dalam penentuan hukum Islam, menyatakan bahwa Qozfl Tasyhir atau pencemaran nama baik merupakan salah satu jarimah atau pada hukum pidana dikenal dengan istilah kriminal, oleh karenanya Islam memberikan hukuman bagi seseorang yang mencemarkan nama baik orang lain, hal ini dengan jelas disebutkan dalam al Qur'an bahwa hukumannya adalah 80 cambukan. Hal ini tertulis dalam Qur'an surah An Nur ayat 6. Dan dalam hadist Rasulullah saw, Qazf merupakan salah satu diantara tujuh dosa besar yang harus dijauhi oleh seseorang, sebagaimana hadist yang diriwayatkan oleh Abu Hurairah r.a.

\section{Metode}

Penelitian ini menggunakan jenis metode penelitian kualitatif yang disebut juga dengan studi kepustakaan dengan pendekatan yuridis normatif. Adapun untuk memperoleh data dari pembahasan ini peneliti menggunakan bahan hukum yang mengikat yaitu undang-undang dan putusan pengadilan. Analisis data menggunakan analisis yuridis yaitu suatu metode analisa yang bersumber pada undang-undang, putusan pengadilan, peraturan dan buku-buku hukum. Pengumpulan data dilakukan melalui studi pustaka dengan mengkaji literature yang berhubungan dengan permasalahan penelitian. Teknik analisis data adalah analisis kualitatif berupa pemaparan, uraian, dan gambaran atas hasil penelitian.

\section{Hasil dan Pembahasan}

\section{Tindak Pidana Pencemaran Nama Baik Melalui Media Sosial menurut Hukum Positif.}

Pengertian pencemaran nama baik dalam bahasa Inggris sering disebut dengan istilah Defamation dan penyebutan di negara lain yaitu Slander, Calumny dan Vilification ketiga istilah ini digunakan untuk pencemaran nama baik secara lisan.

4 Zainiddin Ali, Metode Penelitian Hukum, Jakarta: Sinar Grafika, 2019, hlm 105.

DIKTUM: Jurnal Syariah dan Hukum Volum 19 Nomor 1 Juli 2021 
Saepul Rochman, Haerul Akmal \& Yaffi Jananta Andriansyah:

Pencemaran Nama Baik Melalui...

Dan pencemaran nama baik secara tulisan sering disebut dengan libel. Sedangkan menurut Black's Law Dictionary Defamation adalah perbuatan yang membahayakan reputasi orang lain dengan membuat pernyataan yang salah terhadap pihak ketiga. Di negara- negara Civil Law tindak pidana pencemaran nama baik sering dimasukkan kedalam kategori kejahatan hukum pidana. ${ }^{5}$

Tindak pidana pencemaran nama baik adalah perbuatan pidana yang menyerang nama baik, berupa ucapan, kalimat dan media yang menyerang kehormatan orang lain dan dapat menurunkan harga diri serta martabat pihak yang dicemarkan. Atau penuduhan terhadap seseorang bahwa telah melakukan sesuatu dan disebarkan ke masyarakat luas. ${ }^{6}$ Gangguan atau pelanggaran yang mengarah terhadap reputasi seseorang yang berupa pernyataan yang salah, fitnah, pencemaran nama baik, mengejek dan penghinaan. ${ }^{7}$ Tindak pidana pencemaran, mempunyai unsur-unsur yaitu unsur kesengajaan, unsur menyerang kehormatan dan nama baik, dan unsur dimuka umum. Sedangkan di Indonesia ada beberapa tindak pidana yang dikategorikan sebagai tindak pidana pencemaran nama baik, yaitu:

a) menuduh sesuatu hal secara lisan pasal 310 ayat 1 KUHP,

b) menuduh sesuatu hal dengan tulisan atau gambaran yang disiarkan pasal 310 ayat KUHP,

c) fitnah pasal 311 KUHP dan pasal 36 ayat 5 UU. No. 32 tahun 2002 tentang penyiaran,

d) pengaduan fitnah pasal $317 \mathrm{KUHP}$,

e) Mendistribusikan dan /atau mantrasmisikan dan /atau membuat dapat diaksesnya informasi elektronik dan/ atau dokumen elektronik yang memiliki muatan penghinaan dan/ atau pencemaran nama baik pasal 27 ayat 3 UU ITE.

Pengaturan tindak pidana di Indonesia disebabkan adanya asas legalitas (principle of legality) biasa dikenal dalam bahasa latin "Nullum delictum nulla poena sine praevia lege" (tidak ada pidana tanpa peraturan lebih dahulu). Asas legalitas ini pertama-tama mempunyai bentuk sebagai undang-undang adalah dalam konstitusi

5 Ari Wibowo, "Kebijakan Kriminalisasi Delik Pencemaran Nama Baik di Indonesia”, Jurnal Pandecta, Vol. 7, No. 1, 2012, hlm. 3.

6 Shah Rangga Wira Prastya, "Tinjauan Yuridis Mengenai Sanksi Pidana Terhadap Tindak Pidana Pencemaran Nama Baik Melalui Media Sosial", E-Journal Kertha Wicara Fakultas Hukum Universitas Udayana Fakultas Hukum, Vol. 05, No. 02, Juni 2015, hlm.2.

7 Nudirman Munir, Pengantar Hukum Siber Indonesia, Edisi 3, Depok: Rajawali Pers, 2017, hlm. 292.

DIKTUM: Jurnal Syariah dan Hukum Volum 19 Nomor 1 Juli 2021 
Saepul Rochman, Haerul Akmal \& Yaffi Jananta Andriansyah:

Pencemaran Nama Baik Melalui...

Amerika 1776. Asas ini selanjutnya dimasukkan ke dalam Pasal 4 Code Penal Perancis yang disusun oleh Napoleon Bonaparte. Pasal 1 ayat (1) Wetboek van Strafrecht di Negeri Belanda yang dengan tegas menyatakan, "Geen feit is strafbaar dan uit kraft van eenedaaraan voorafgegane wetelijke strafbepaling". Selanjutnya asas tersebut dimuat dalam Pasal 1 ayat (1) KUHP Indonesia. ${ }^{8}$

Asas legalitas pada dasarnya bermuara pada nilai-nilai kepastian hukum yang berimplikasi pada efektivitas penegakan hukum pidana dan dapat mengesampingkan kemanfaatan dan keadilan. Sebab secara sosiologis perubahan masyarakat sering kali lebih cepat dibandingkan perubahan hukum. Efektivitasnya sangat tergantung pada sejauhmana kepekaan aturan normatif hukum mampu mengantisipasi terhadap perubahan sosial yang terjadi, gaya hidup, budaya dan keinginan manusia, baik positif dan negatif dari setiap individu-individu dalam masyarakat untuk memanfaatkan hasil dari kemajuan teknologi tersebut, yang seyogianya harus mampu diantisipasi oleh aturan hukum. ${ }^{9}$

Menurut Kasubdit Cyber Ditreskrimus Poda Metro Jaya AKBP Roberto Gomgom Pasaribu mengatakan bahwa dari seribu-an kasus cybercrime, kasus pencemaran nama baik melalui media sosial: "Rata-rata paling banyak itu kasus pencemaran nama baik dan provokasi". Linimasa di media sosial menjadi sarana paling potensial melakukan kejahatan siber. "Internet ini boarderless, pelaku bisa melakukan kejahatannya dimana saja dan kapan saja." Masalah utama dalam sistem hukum siber di indonesia yaitu:

(1) masih banyaknya kendala dalam menjaga kepastian hukum dalam sistem hukum di Indonesia;

(2) masih terbatasnya penguasaan hukum siber di Indonesia; dan

(3) sumber daya manusia yang mempunyai kemampuan tentang hukum siber masih terbatas. Maka dari itu penguasaan hukum siber di Indonesia harus menyebar ke seluruh wilayah di Indonesia. ${ }^{10}$

Upaya penyebaran hoax dalam bidang politik sangat gencar dilakukan, seperti yang terjadi pada tahun 2018-2019 pemilukada provinsi DKI Jakarta. Dikarenakan kemajuan teknologi yang sangat pesat dan sumber daya manusia belum siap menerima kemajuan di bidang TIK ini sehingga berdampak kepada

8 Sri Rahayu, "Implikasi Asas Legalitas Terhadap Penegakan Hukum dan Keadilan”, Jurnal Inovatif, Volume VII Nomor III September 2014, hlm. 2

${ }_{9}^{9}$ Maharidiawan Putra, "Hukum dan Perubahan Sosial: Tinjauan Terhadap Modernisasi Dari Aspek Kemajuan Teknologi", Jurnal Morality Volume 4 Nomor 1, Juni 2018, hlm. 47.

${ }^{10}$ Nudirman Munir, Op.Cit, hlm. 21.

DIKTUM: Jurnal Syariah dan Hukum Volum 19 Nomor 1 Juli 2021 
Saepul Rochman, Haerul Akmal \& Yaffi Jananta Andriansyah:

Pencemaran Nama Baik Melalui...

tatanan dalam masyarakat. ${ }^{11}$ Pada tahun 2016 Undang Undang ITE diamandemen dengan menambahkan norma dan penjelasan tentang tindak pidana pencemaran nama baik di dalam Undang Undang No. 19 Tahun 2016 tentang perubahan atas Undang Undang No. 11 tahun 2008 tentang informasi dan transaksi elektronik.

Di dalam undang-undang tentang penyiaran, tindak pidana pencemaran nama baik dijelaskan pada pasal 36 ayat 5, yang berisi sebagai berikut, isi siaran yang dilarang yaitu berisi fitnah, menghasut atau menyesatkan atau berita bohong, menonjolkan unsur kekerasan, cabul, perjudian, penyalahgunaan narkotika dan obat terlarang atau mempertentangkan suku, agama, ras dan antar golongan. Sedangkan di dalam undang-undang ITE tindak pidana pencemaran nama baik diatur pada pasal 27 ayat (3).

Kasus Galih Bayu Ginanjar, Pablo Benua dan Rey Utami, yaitu mereka melakukan dan menyuruh melakukan perbuatan dengan sengaja dan tanpa hak mendistribusikan dan/ atau mentransmisikan dan/ atau membuat dapat diaksesnya informasi elektronik dan/atau dokumen elektronik, yang memiliki muatan melanggar muatan kesusilaan yang mengakibatkan kerugian bagi orang lain. Yaitu membuat Video berdurasi 32 menit 6 detik yang berisi tanya jawab berupa kehidupan masa lalu Galih, menceritakan kehidupan mantan isterinya yaitu Fairuz El Fouz, mengandung konten kesusilaan yang menyinggung organ intim dari saudari Fairuz yang di upload ke Channel Youtube Rey Utami dan Benua. Dalam kasus ini majelis hakim menjatuhkan pidana kepada Terdakwa I Pablo Putra Benua oleh karena itu dengan pidana penjara selama 1 (satu) tahun dan 8 (delapan) bulan, Terdakwa II Rayie Utami alias Rey Utami dengan pidana penjara selama 1 (satu) tahun dan 4 (empat) bulan, Terdakwa III Galih Ginanjar Saputra dengan pidana penjara selama 2 (dua) tahun dan 4 (empat) bulan.

Berdasarkan uraian di atas, dapat dinyatakan bahwa dalam persoalan penerapan hukum seorang hakim mempunyai kebebasan untuk menjatuhkan putusan kecuali putusan sela, yaitu suatu proses mengakhiri perkara/sengketa dengan menggunakan konsep-konsep mengadili, seorang hakim diberikan kebebasan untuk menjatuhkan putusan sesuai dengan apa yang diyakininya berdasarkan serangkaian proses pembuktian yang telah mendahului sebelumnya, kebebasan tersebut dijamin oleh undang-undang sebagai kewenangan yang bebas

${ }^{11}$ Anton Hendrik Samudra, "Pencemaran Nama Baik dan Penghinaan Melalui Media Teknologi Informasi Komunikasi di Indonesia Pasca Amandemen UU ITE", Jurnal Hukum dan Pembangunan Universitas Indonesia, Vol. 50, No. 1, 2020, hlm. 92.

DIKTUM: Jurnal Syariah dan Hukum Volum 19 Nomor 1 Juli 2021 
Saepul Rochman, Haerul Akmal \& Yaffi Jananta Andriansyah:

Pencemaran Nama Baik Melalui...

dan merdeka dari segala pengaruh apapun, baik dari lingkup intervensi internal maupun eksternal ${ }^{12}$

Landasan yuridis dan filosofis kekuasaan kehakiman sebagai lembaga yang mandiri dan bebas dari segala bentuk campur tangan dari luar, sebagaimana yang dikehendaki di dalam Pasal 24 UUD 1945, bahwa kekuasaan kehakiman adalah kekuasaan negara yang merdeka untuk menyeleggarakan peradilan guna menegakkan hukum dan keadilan berdasarkan Pancasila dan UUD 1945, demi terselenggaranya negara hukum Republik Indonesia. ${ }^{13}$

Menurut ketentuan Pasal 8 ayat (2) Undang-Undang Nomor 48 Tahun 2009 tentang Kekuasaan Kehakiman juga disebutkan merupakan tugas hakim untuk menilai sifat baik dan jahat dari terdakwa, akibatnya suatu pasal yang menentukan batasan tindak pidana dapat saja berkurang hukumnya dan bertambah sepanjang tidak melebihi batas maksimal yang ditentukan oleh peraturan perundangundangan.

\section{Tindak Pidana Pencemaran Nama Baik Dalam Media Sosial Menurut Hukum Pidana Islam}

Menurut hukum pidana Islam mencemarkan nama baik, menuduh dan mengolok-olok seseorang ataupun suatu golongan sungguh dilarang perbuatan tersebut dikategorikan sama dengan Jarimah Qadzf (Tuduhan Zina). Menurut Abdul Qadir Audah, Jarimah Qadzf terbagi menjadi 2 (dua) macam yaitu, Qadzf yang dihukum dengan had dan Qadzf yang dihukum dengan pengasingan (ta'zir). Qadzf yang dihukum dengan had adalah menuduh seorang yang baik-baik berzina dan mengingkari nasabnya. Sedangkan Qadzf atau Tasyhir yang dihukum dengan ta'zir adalah menuduh seseorang dengan tuduhan selain zina dan tidak mengingkari nasabnya, yang dimaksud adalah perbuatan mencaci dan memaki orang lain. ${ }^{14}$

Menurut Imam Jalaludin di dalam buku tafsir Imam Jalalain, pencemaran nama baik dibagi menjadi 3 (tiga) bagian:

1. sukhriyyah yaitu meremehkan orang lain karena sebab tertentu,

2. lamzu yaitu menjelek-jelekan orang lain dengan cacian dan makian;

${ }_{12}$ Darmoko Yuti Witanto dan Arya Putra Negara Kutawaringin, Diskresi Hakim Sebuah Instrumen Menegakkan Keadilan Substantif Dalam Perkara-Perkara Pidana, Cetakan Pertama, Alfabeta: Bandung, 2013, hlm. 192.

${ }^{13}$ Firman Floranta Adonara, "Prinsip Kebebasan Hakim dalam Memutus Perkara Sebagai Amanat Konstitusi", Jurnal Konstitusi, Volume 12, Nomor 2, Juni 2015, hlm. 219

${ }^{14}$ M. Nurul Irfan, Masyrofah, Figh Jinayah, Cetakan Pertama, Jakarta: Amzah, 2019, hlm. 42

DIKTUM: Jurnal Syariah dan Hukum Volum 19 Nomor 1 Juli 2021 
Saepul Rochman, Haerul Akmal \& Yaffi Jananta Andriansyah:

Pencemaran Nama Baik Melalui...

3. Tanabuz yaitu memanggil orang lain dengan nama yang buruk atau panggilan yang jelek. ${ }^{15}$

Dengan demikian tindak pidana pencemaran nama baik merupakan Qadzaf yang dihukum dengan $t a^{\prime} z i r$ dan keputusan berada di tangan hakim dan penguasa. Tindak pidana ini sungguh merugikan korban dan sudah terpenuhi 3 (tiga) unsur pencemaran nama baik, yaitu unsur kesengajaan, unsur di muka umum, dan unsur menyerang kehormatan atau martabat. Hal demikian juga masuk dalam salah satu aspek maqoshid syariah, yaitu pennjagaan pada jiwa, penjagaan pada jiwa dimaksudkan agar seseorang tidak minciderai, melukai, menyakiti dan membunuh karakter orang lain, serta menciptakan rasa aman dalam diri seseorang. ${ }^{16}$ Dan menurut hemat penulis bahwa hal ini bisa saja menjadi dasar hukum pidana Islam atas pencemaran nama baik.

Madzhab yang menentukan masa tahanan ta'zir adalah madzhab Syafi'i, yaitu tidak lebih dari satu tahun. Imam Syafi'i mengqiyaskan tindak pidana ini dengan hukuman pengasingan pada hukuman zina. Sementara madzhab lain tidak mengqiyaskannya dengan hukuman pengasingan juga membolehkan menggabungkan hukuman penjara dengan hukuman pukulan, apabila dinilai hukuman belum cukup, madzhab Syafi'i menyaratkan agar diterapkan dengan sesuai yaitu sebagai hukuman penyempurna. Apabila memukul pelaku setengah pukulan yang ditetapkan oleh hukuman $t a^{\prime} z i r$, maka mendapat setengah hukuman penjara dan apabila mendapat seperempat cambukan, maka mendapat hukuman penjara tiga perempat masa tahanan. ${ }^{17}$

Hukuman penjara adalah hukuman kedua bagi pelaku yang diputuskan berdasarkan kebebasan hakim atau merupakan pilihan bagi para hakim. Tujuan hukuman penjara dalam Islam dimaksudkan untuk mendidik ( $\left.t a^{\prime} d i b\right)$ atau perbaikan bagi pelaku, tidak hanya bertujuan untuk mencapai kepastian hukum semata. Model penyelesaian perkara dalam pidana Islam terbagi menjadi 2 (dua) yaitu:

(1) Model Penyelesaian Diskresif (istihsan) yang diperkenalkan oleh madzhab

Hanafi. Model ini adalah penetapan hukum dari seorang hakim (qadhi) terhadap suatu masalah yang menyimpang dari ketentuan hukum yang diterapkan pada

${ }^{15}$ Imam Jalaluddin, Tafsir Jalalain, Sinar Baru Algensindo, Bandung, 2010, hlm. 428.

${ }^{16}$ Mulyono Jamal, Haerul Akmal dkk, Implementasi Wisata Syariah Lombok dalm Perspektif Maqoshid Syariah, Al Istinbath: Jurnal Hukum Islam, Vol 4 No 2, November 2019, Hlm 143160.

${ }_{17}$ Abdul Qadir Audah, At-Tasyri' Al-Jinaiy Al-Islami Muqarinan bi Al-Qanun Al-Wad'i, Jilid Kedua, Beirut: Muassasah ar-Risalah, 1992, hlm. 430.

DIKTUM: Jurnal Syariah dan Hukum Volum 19 Nomor 1 Juli 2021 
Saepul Rochman, Haerul Akmal \& Yaffi Jananta Andriansyah:

Pencemaran Nama Baik Melalui...

masalah-masalah yang serupa, karena alasan yang lebih kuat yang menghendaki dilakukannya penyimpangan itu. ${ }^{18}$

(2) Model Penyelesaian Benefical (istihlah) yang diperkenalkan oleh Madzhab Maliki dan Syafi'i. Model ini adalah menetapkan hukum yang tidak ada nashnya dan mashlahah yang dianggap sah untuk ditentukan menjadi hukum syar'i adalah mashlahat yang tidak mempunyai ketentuan syara. ${ }^{19}$

Implikasi penerapan dua model penyelesaian perkara ini memungkinkan adanya proses mediasi bagi pelaku dan korban. Sesuai dengan konsep penegakan hukum restoratif di Indonesia sebagaimana tercantum dalam surat edaran kapolri, peraturan kejaksaan dan keputusan direktur jenderal badan peradilan umum mahkamah agung sebagai berikut:

1. Surat Edaran Kapolri Nomor: SE/8/VII/2018 tentang Penerapan Keadilan Restoratif (Restorative Justice) Dalam Penyelesaian Perkara Pidana, yang mengatur bahwa perkara yang dapat diselesaikan melalui mekanisme keadilan restoratif adalah perkara pidana dengan kerugian kecil yang merupakan kategori tindak pidana ringan, dan tidak dapat diterapkan terhadap tindak pidana berat yang mengakibatkan korban manusia;20

2. Peraturan Kejaksaan Republik Indonesia No. 15 tahun 2020 Tentang Penghentian Penuntutan Berdasarkan Keadilan Restoratif pada pasal 5 ayat (1) disebutkan bahwa perkara tindak pidana dapat ditutup demi hukum dan dihentikan penuntutannya berdasarkan keadilan restoratif dengan ketentuan tersangka baru pertama kali melakukan tindak pidana, ancaman pidana denda atau diancam penjara tidak lebih dari 5 (lima) tahun dan nilai barang bukti atau kerugian tidak lebih dari Rp. 2.500.000,00 (dua juta lima ratus ribu rupiah); dan,

3. Keputusan Direktur Jenderal Badilum No. 1691/DJU/SK/PS.00/12/2020 tentang Pemberlakuan Pedoman Penerapan Keadilan Restoratif (Restorative Justice) yang memerintahkan pada diktum Kedua agar seluruh hakim pengadilan negeri untuk melaksanakan pedoman penerapan keadilan restoratif. Alasan penerapan keadilan restoratif adalah bahwa perkembangan

${ }^{18}$ Muhammad Sulaiman dan Abdullah Al-Asyraf, Al-Wadhih Fi Ushul al-Figh Lil Mubtadiin, Amman: Dar al-Nafais 1992, hlm. 140

${ }^{19}$ Nur Asiah, "Istishlah Dan Aplikasinya Dalam Penetapan Hukum Islam", Jurnal Hukum Diktum, Volume 14, Nomor 2, Desember 2016, hlm. 152.

20 Rahman Amin, Muhammad Fikri Al Aziz, dan Iren Manalu, "Penerapan Keadilan Restoratif Dalam Penyelesaian Perkara Kecelakaan Lalu Lintas Berat Di Kepolisian Resort Metro Jakarta Pusat", Krtha Bhayangkara, Vol. 14 No. 1 2020, hlm. 12

DIKTUM: Jurnal Syariah dan Hukum Volum 19 Nomor 1 Juli 2021 
Saepul Rochman, Haerul Akmal \& Yaffi Jananta Andriansyah:

Pencemaran Nama Baik Melalui...

sistem pemidanaan bukan lagi bertumpu pada pelaku melainkan telah mengarah pada penyelarasan kepentingan pemulihan korban dan pertanggungjawaban pelaku tindak pidana.

\section{Kesimpulan}

Tindak pidana pencemaran nama baik adalah perbuatan yang membahayakan reputasi orang lain dengan membuat pernyataan yang salah terhadap pihak ketiga. Perbuatan pidana yang menyerang nama baik, berupa ucapan, kalimat dan media yang menyerang kehormatan orang lain dan dapat menurunkan harga diri serta martabat pihak yang dicemarkan. Tuduhan terhadap seseorang bahwa telah melakukan sesuatu dan disebarkan ke masyarakat luas. Titik temu antara hukum positif dengan hukum Islam bahwa sanksi bagi pelaku pencemaran nama baik didasarkan keputusan hakim dan penguasa atau mendapat hukuman $t a^{\prime} z i r$.

\section{Daftar Pustaka}

\section{Buku}

Ali, Zainiddin. 2019, Metode Penelitian Hukum, Jakarta: Sinar Grafika

Audah, Abdul Qadir. 1992, At-Tasyri' Al-Jinaiy Al-Islami Muqarinan bi Al-Qanun AlWad'i, Jilid Kedua, Beirut: Muassasah ar-Risalah

Darmoko Yuti Witanto dan Arya Putra Negara Kutawaringin, 2013. Diskresi Hakim Sebuah Instrumen Menegakkan Keadilan Substantif Dalam Perkara-Perkara Pidana, Cetakan Pertama Alfabeta: Bandung.

Mansur, Dikdik M Arief dan Elisatris Gultom, 2009. Cyber Law Aspek Hukum Teknologi Informasi, Bandung: Refika Aditama

Muhammad, Sulaiman dan Abdullah Al-Asyraf, 1992, Al-Wadhih Fi Ushul al-Figh Lil Mubtadiin, Amman: Dar al-Nafais.

Munir, Nudirman. 2017. Pengantar Hukum Siber Indonesia, Edisi 3, Depok: Rajawali Pers

Imam Jalaluddin, 2010. Tafsir Jalalain, Sinar Baru Algensindo, Bandung

Irfan, M. Nurul dan Masyrofah, 2019. Fiqh Jinayah, Cetakan Pertama, Jakarta: Amzah

DIKTUM: Jurnal Syariah dan Hukum Volum 19 Nomor 1 Juli 2021 
Saepul Rochman, Haerul Akmal \& Yaffi Jananta Andriansyah:

Pencemaran Nama Baik Melalui...

\section{Artikel Jurnal}

Adonara, Firman Floranta "Prinsip Kebebasan Hakim dalam Memutus Perkara Sebagai Amanat Konstitusi", Jurnal Konstitusi, Volume 12, Nomor 2, Juni (2015).

Ahmad, Amar. "Perkembangan Teknologi Komunikasi dan Informasi: Akar Revolusi dan Berbagai Standarnya", Jurnal Dakwah Tabligh, Vol. 13, No. 1, Juni (2012).

Amin, Rahman Muhammad Fikri Al Aziz, dan Iren Manalu, "Penerapan Keadilan Restoratif Dalam Penyelesaian Perkara Kecelakaan Lalu Lintas Berat Di Kepolisian Resort Metro Jakarta Pusat", Krtha Bhayangkara, Vol. 14 No. 1 (2020).

Asiah, Nur. “Istishlah Dan Aplikasinya Dalam Penetapan Hukum Islam”, Jurnal Hukum Diktum, Volume 14, Nomor 2, Desember (2016).

Maharidiawan Putra, "Hukum dan Perubahan Sosial: Tinjauan Terhadap Modernisasi Dari Aspek Kemajuan Teknologi", Jurnal Morality Volume 4 Nomor 1 Juni (2018).

Prastya, Shah Rangga Wira. “Tinjauan Yuridis Mengenai Sanksi Pidana Terhadap Tindak Pidana Pencemaran Nama Baik Melalui Media Sosial", E-Journal Kertha Wicara Fakultas Hukum Universitas Udayana Fakultas Hukum, Vol. 05, No. 02, Juni (2015).

Rajab, Achmadudin “Urgensi Undang-Undang Nomor 19 Tahun 2016 Tentang Perubahan Atas Undang-Undang Nomor 11 Tahun 2008 Tentang Informasi dan Transaksi Elektronik Sebagai Solusi Guna Membangun Etika Bagi Pengguna Media", Jurnal Legislasi Indonesia, Vol. 14 No. 04, (2017).

Rahayu, Sri "Implikasi Asas Legalitas Terhadap Penegakan Hukum dan Keadilan", Jurnal Inovatif, Volume VII Nomor III September (2014).

Samudra, Anton Hendrik. "Pencemaran Nama Baik dan Penghinaan Melalui Media Teknologi Informasi Komunikasi di Indonesia Pasca Amandemen UU ITE", Jurnal Hukum dan Pembangunan Universitas Indonesia, Vol. 50, No. 1, (2020).

Wibowo, Ari. “Kebijakan Kriminalisasi Delik Pencemaran Nama Baik di Indonesia, Jurnal Pandecta", Vol. 7, No. 1, (2012).

DIKTUM: Jurnal Syariah dan Hukum Volum 19 Nomor 1 Juli 2021 